\title{
Evolution of the Soil Landscape in the Sand Region of the Arctic Coastal Plain as Exemplified at Atkasook, Alaska*
}

\author{
K. R. EVERETT
}

\begin{abstract}
The Meade River region around the village of Atkasook, Alaska typifies much of the Arctic Coastal Plain underlain by aeolian sands. The forms and patterns of the landscape are formed mainly by ancient and active sand dunes and by channel shifts of the Meade River. Nearly all landforms, including those designated as primary, have had a polycyclic history throughout the last 10,000 years. The oldest and/or most stable landforms are low, broad dune ridges, interfluves, and lake divides. These have well-drained, reddish sandy soils with a distinct eluvial horizon and represent very extensive periods of development. Less well-drained sloping surfaces surrounding dune ridges and other primary landforms are covered by tussock tundra and all soils show the effect of cryoturbation. They range in age from 5,000 to 6,000 years. The development and stabilization of the primary landforms and the evolution of their soils are illustrated by similar much younger landforms. Generally, lowland areas associated with drained lake basins and cutoff meanders have a polygonal surface pattern and organic soils that range in age from a few thousand to at least 9,500 years. The majority of the polygonized terrain ranges in age from 4,000 to 5,000 years. Younger surfaces associated with the present course of the Meade River consist of alluvial terraces and active or partially stabilized sand dunes. The soils show little profile development. Their maximum age is on the order of 1,000 years.
\end{abstract}

RESUME. La region de Meade River, entourant le village d'Atkasook, Alaska, personnifie bien cette partie de la plaine cotiere arctique recouverte par les sablies eoliens. D'anciennes et actives dunes de sables, des changements de cours de la "Meade River" controlent en grande partie les formes et types de paysage. Presque toutes les images morphologiques, y comprises celles indiquees commes primaires, ont eu une histoire polycyclique pendant les 10.000 dernières annees. Les images morphologiques les plus anciennes et les plus stables sont les larges alignements dunaires de peu d'amplitude, les diverticules interfluviaux et des lacs. Ceux-ci ont bien drainé les sols sableux rougeatres avec un horizon alluvial particulier et representent 3.000 à 10.000 annees de sédimentation. Les surfaces pentees entourant les alignements dunaires et autres traits morphologiques primaires, sont moins bien drainés. Elles sont recovertes d'une toundra de touffe d'herbe bien developpee et tous les sols montrent des effets to "cryoturbation" to 5.000 à 6.000 ans. Des traits morphologiques semblables beaucoup plus recents fournissent un apercu du developpement et de la stabilité des traits morphologiques primaires et de l'evolution de leurs sols. Les basses terres sont associees avec des bassins de lacs draines et de meandres rompus; elles ont genéralement des sols organiques de type polygonal dont l'age s'etablit de quelques milliers d'annees, à au moins 9.500 ans. La majorite des sols polygonaux a entre 4.000 at 5.000 ans. Des dépôts réents sont associes avec le cours actuel de la Meade River, ils sont formes de terrasses alluviales et de dunes de sable actives et/ou partiellement stabilisees. Les sols montrent un petit profil de developpement et leur age se situe dans une fourchette de 1.000 ans.

\section{INTRODUCTION}

Investigation of the soils of the Atkasook region was undertaken as part of the RATE (Research Applied to the Tundra Environment) project and was designed to provide baseline data on soils and their chemistry for use in

*Contribution No. 379 of the Institute of Polar Studies, The Ohio State University, Columbus, Ohio 43210 
conjunction with the botanical programs and nutrient cycling projects. In a broader sense the intent of this study was to develop a scenario for soil-landform evolution in this sandy area of the coastal plain.

\section{SETTING}

The village of Atkasook and the surrounding study area $\left(71^{\circ} 28^{\prime} \mathrm{N} ; 157^{\circ}\right.$ $\left.25^{\prime} \mathrm{W}\right)$ lies in the northwest portion of the wedge of Pleistocene sands and sand dunes within the Coastal Plain Province (Wahrhaftig, 1965) that extend westward from near the Colville River to the Nigisaktuvik River (Fig. 1).

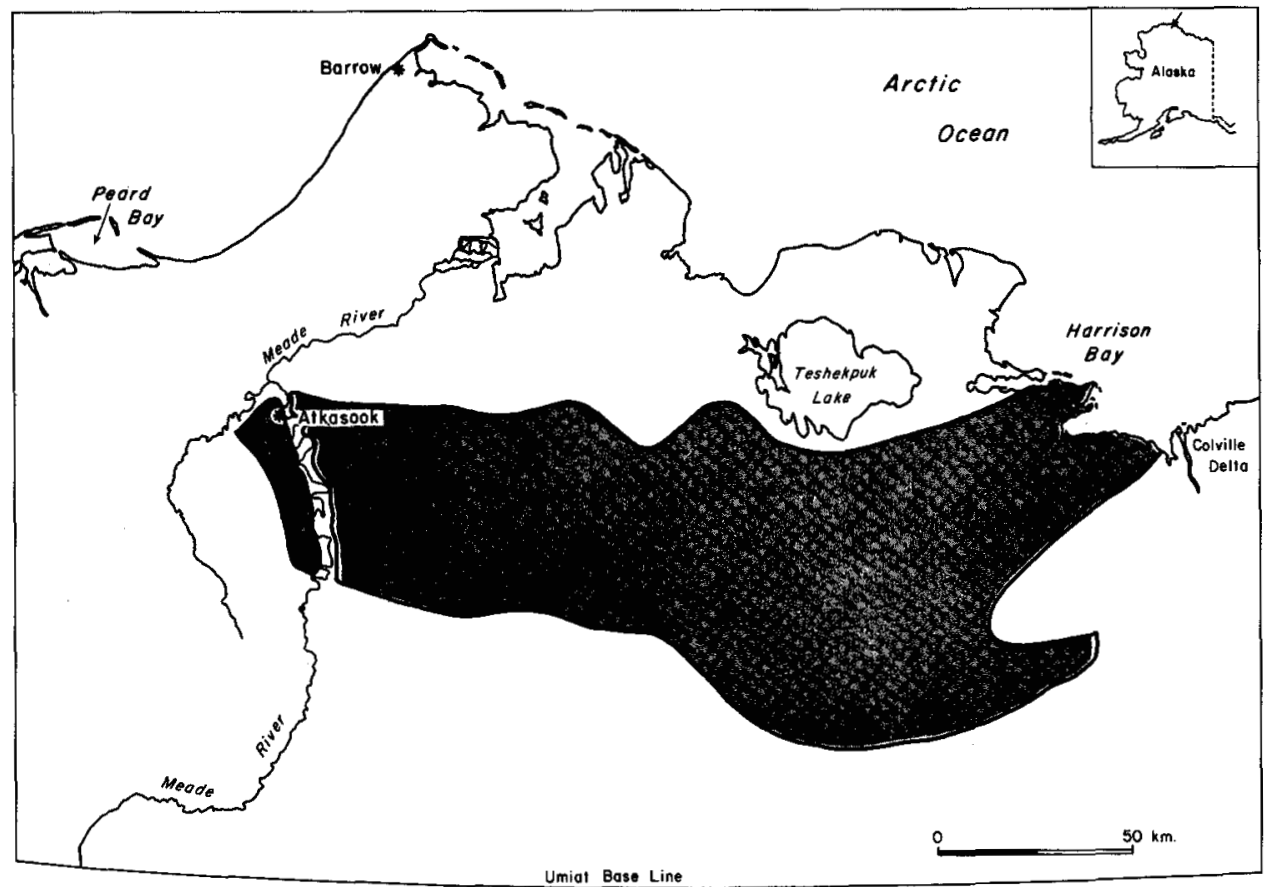

FIG. 1. Regional distribution of aeolian deposits on the arctic coastal plain. Modified from fig. 65 Alaska Regional Profiles, Arctic Region. Selkregg (1975).

Superficially, the area resembles the littoral tundra of the north part of this province (Cantlon, 1965), as typified by the region south of Barrow and that near Prudhoe Bay. The Atkasook and central Meade River region differ from these more northern areas in several important respects. Lakes in this region are less numerous, are not as strongly oriented to the northwest, and have much more irregular shorelines. Rivers and streams display an extreme, often regular meander pattern (Fig. 2), in contrast to their courses within the silt terrains to the north and south. The larger rivers have incised channels. The Meade River, especially that portion which traverses the study area, has cut through 3 to $10 \mathrm{~m}$ of unconsolidated Pleistocene and Holocene sediments, principally the sandy Meade River Member of the Gubik Formation (Black, 


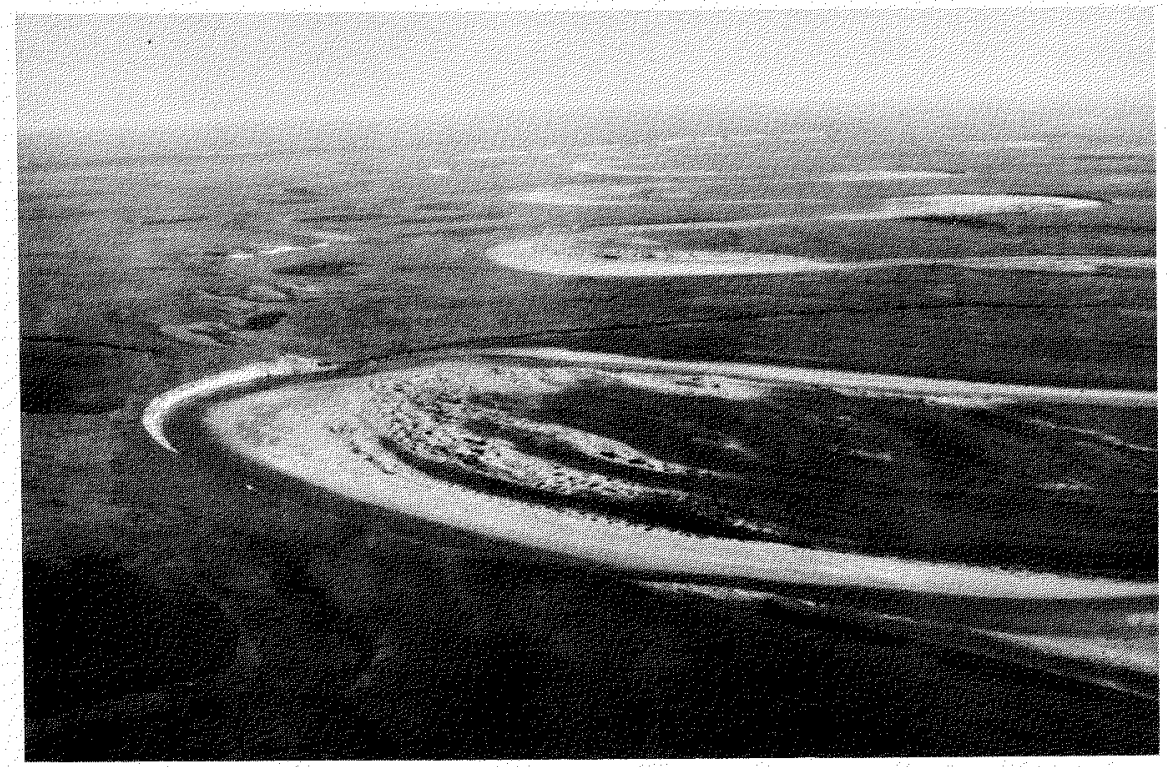

FIG. 2. Meander loops characteristic of the Meade River and other rivers that traverse the sand region of the coastal plain. Active dune areas lie adjacent to point bars. Note low level terrace and abandoned and erosionally smoothed cutbanks in center and right center respectively.

1964), and now flows on the underlying, jointed Jurassic and Cretaceous sandstones and siltstones.

For at least the last 10,000 years, the Meade River has meandered within a relatively broad valley (up to $1 \mathrm{~km}$ in width), that today contains numerous high level flood plain terraces, some of which display meander scars, segmented oxbow lakes, and complexes of subparallel, crescentic point bar deposits. The outside of active meander loops commonly are flanked by nearly vertical cliffs of sand. Similar cliffs, whose angle of slope has been reduced by mass-wasting, flank many abandoned meanders. In both cases, deposits of sand may occur at the top of the cliff and slope gently inland. Point bar deposits on the inside of meander loops are the source of sands that form the active serrate-margin dune fields that extend inland for several hundred meters on terrace remnants (Fig. 2).

Linear interfluves and interlake divides, whose surface pattern is broadly similar to, but appear to be of larger scale than the active dune areas marginal to the present meanders of the Meade River, lie beyond the meander belt. These inland features are several meters to several tens of meters high. They are interpreted as representing primarily ancient dunes developed from sands of the Meade River Member of the Gubik Formation. In a manner similar to the dunes of south Texas and southern Chile, these ancient dunes have had considerable control on both the distribution and form of the larger lakes in this region (see description in Kaczorowski, 1977). Analogous forms have been observed in the Fish Creek area, approximately $230 \mathrm{~km}$ to the east (Lawson, et al., 1978), and Kealok Creek (Carter and Robinson, 1977). These 
old dune ridges represent primary land form elements that are at least contemporaneous with and probably predate the Meade River. They generally lack significant surface pattern and are covered by a sparse and unique vegetation. The rather uniform slopes descending from the ridges to lakes or the basins of former lakes are covered with small tussocks. The tussock pattern is analogous to that of larger tussocks in the northern portion of the Arctic Foothills Province to the south.

The lowland areas in the basins of former lakes or former river terraces are characterized by a cellular pattern. In areas of younger terrain $(2,000$ to 4,000 years) associated with elevated terraces, meander cutoffs and some drained lakes, the surface pattern consists of regular, aligned cells or polygons that are $10 \pm \mathrm{m}$ diameter (Fig. 3). The alignment is clearly controlled by boundary

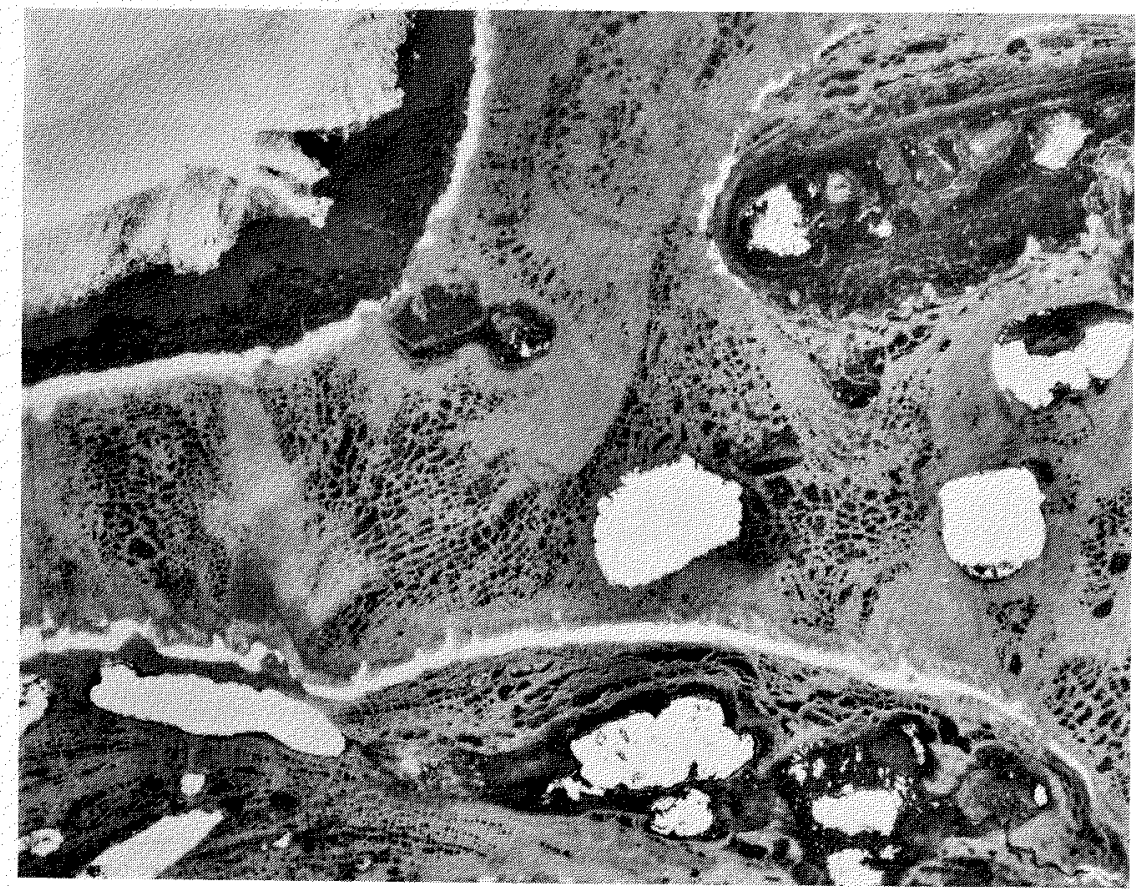

FIG. 3. Portion of air photograph (BAR-147-069) of the Atkasook area showing abandoned cut banks of the Meade River (outlined by snow drifts). Active deflation pits can be seen along the crest. Stabilized sand areas cover portions of the cellular microrelief in left center of the photo. Strangmoor and orthogonal polygons occur in and adjacent to partially drained lake basins, upper right and bottom center.

features such as lake shores and point bars. On older terrains of 4,000 to 5,000 years in age that occur beyond the Meade River meandeg belt, an aligned cellular pattern also persists. However, the individual cells are distinctly ovoid in shape with their primary axes extending tens to a hundred or more meters. In some cases, margins of long ago drained lakes or primary land forms control alignment. This alignment may be interrupted by low, linear, sandy divides. In other cases, areas of the pattern are completely or partially 
buried by sand blankets. In the study area such sand covers result from aperiodic dune formation associated with shifts in the meander pattern of the Meade River, the erosion of some lake bluffs or from the temporary brief exposure of the sand floor of newly drained lakes. These aeolian outbreaks in the Atkasook area probably span the last 10,000 years or more.

SOILS

\section{Introduction}

Soils are the product of a complex interaction involving: (1) climate, especially as it governs the moisture and temperature regime of the materials in which the soil forms, (2) the mineralogic composition and texture of these parent materials, (3) the amount and kind of vegetation contributing organic materials and their decomposition products to the surface, (4) the landform element (macro- or microscale), on which the soil occurs, and which governs its drainage, receipt of solar radiation, amount of wind abrasion and snow cover, (5) the length of time over which soil formation occurs, and finally (6) the stability of the site. The stability of the site is recognized in various ways. For example, in the soil order of Vertisols (Soil Survey Staff, 1975), moisture regulated expansion and contraction of certain clay minerals produces deep and wide cracks in the soil into which rain washes organic and other materials. The incorporated organic materials and deformation produced by the cracks contribute to a complex soil morphology and in most cases a patterned microrelief (Costin, 1955). In the U.S. classification system, interrupted soil horizons are described by the term ruptic. In the Canadian soil classification system, site instability is described by the term turbic. In permafrost areas, site instability (collectively encompassed by the term cryoturbation) commonly produces a patterned microrelief and a complex pattern of soils.

With these considerations in mind, soils must be viewed with regard to the landforms on which they occur because of their different ages and their instability.

Meade River soils belong to three taxonomic orders. The first, Entisols, are soils showing little or no evidence of the development of horizons. This situation may be due to recent deposition or constant disturbance so that the processes of soil formation have had insufficient time to alter the parent material or, the soil forming processes are too impotent at this northern latitude to leave their imprint, especially on the quartz-rich sandy parent materials that are relatively inert chemically.

The second order, the Inceptisols, are composed of a large and diverse group of soils formed under generally humid conditions. They display the imprint of the soil forming factors in weakly developed horizons that are morphologically, chemically and/or physically distinguishable. Although release and translocations of bases $\left(\mathrm{Ca}^{++}, \mathrm{Mg}^{++}\right.$, or $\left.\mathrm{K}^{+}\right)$, iron, or aluminum occur, weatherable minerals remain. Factors governing the degree to which horizon differentiation occurs are the same as those of the Entisols. In the 
Meade River area and throughout the aeolian wedge of the coastal plain, Inceptisols are largely confined to the poorly- and very poorly-drained ancient lake basins. On these wet sites the combination of cold temperatures and anaerobic conditions favor the accumulation of organic materials above the sandy mineral horizons. Thus, it is common to encounter Inceptisols with thick and diagnostic horizons, referred to as histic epipedons in taxonomic nomenclature.

Organic soils (Histosols) comprise the third soil order found in the Atkasook area. They are composed of the remains of water tolerant plants, mostly sedges, that have accumulated under waterlogged and largely anaerobic conditions. Minimally, to qualify as a Histosol, the soil must have between 12 and 18 percent organic carbon ( 21 to $31 \%$ organic matter) and a thickness of at least $40 \mathrm{~cm}$ (16 inches). Histosols are common on the Arctic Coastal Plain but because of the generally low volumes of organic matter produced in this cold region, they tend to be rather thin. In areas where maximum summer thaw is less than $40 \mathrm{~cm}$, examination of permanently frozen soil materials is necessary to verify these minimum thickness requirements (Soil Survey Staff, 1975; Everett and Parkinson, 1977). In many areas of the coastal plain and especially the Atkasook area, mineral additions to the soil in the form of loess or sand may dilute the organic materials below the percentage necessary to meet the minium organic carbon requirements. As a result of this mineral dilution and the general thinness of organic materials, there is much inter-gradation with Inceptisols (Histic Pergelic Cryaquepts) and in some instances with Entisols.

The organic materials in a Histosol may be little decomposed and fibrous (termed fibric), moderately decomposed (hemic), or completely decomposed material (sapric). A profile may have materials in only one decomposition state or have all three states present in separate horizons. The primary decomposition state determines the subgroup name of the soil. The sequence and characteristics of the horizons, including mineral horizons, pollen analyses and ${ }^{14} \mathrm{C}$ dating of the organics make these soils useful in reconstructing the vegetation and climate of the past.

The following discussion will consider the Meade River soils at the suborder and great group level of classification in relation to the landforms on which they most commonly occur. At the great group level, temperature is an important criterion. The prefix $C r y$ applied to the suborder name denotes a mean annual temperature at $50 \mathrm{~cm}$ between $0^{\circ} \mathrm{C}$ and $8^{\circ} \mathrm{C}$. The term Pergelic denotes the presence of permafrost and a mean annual temperature less than $0^{\circ} \mathrm{C}$ (a contradiction inherent in the taxonomy).

\section{Entisols}

These soils with little chemical or physical differentiation evident in their profiles account for about 14 percent of the area investigated around Atkasook. Two suborders are recognized: Pergelic Cryopsamments (13\% of the area) and tentatively, Pergelic Cryofluvents (1\%). Both suborders occur throughout the coastal plain but the Cryopsamments are especially significant 
in the wedge of sandy sediments extending westward from the Colville River (Fig. 1). They are also of local significance for short distances to the west of the deltas of some of the major north-flowing rivers of the coastal plain, for example, the Sagavanirktok River (Everett and Parkinson, 1977). On a regional basis, Entisols (including the suborder Orthents which are the gravelly Entisols of river terraces and not found in the Atkasook area) probably occupy less than 1 percent of the coastal plain province. They are however, much more significant components of the soil-landscape in the foothills and mountain regions to the south.

Pergelic Cryopsamments:Pergelic Cryopsamments are developed on the well sorted dune sands of the area (Rickert and Tedrow, 1966). Some dunes are active, others quasi-stabilized by grasses and willows and still others are stable and very old. Thus the degree of profile expression within the Cryopsamment suborder ranges widely. The most intense expression of the soil forming factors is found in the Cryopsamments of the primary landforms. Because of an incomplete cover of lichen-dominated vegetation, especially (Alectoria nigricans) organic matter addition to the soil is not large. A radiocarbon age determination on A1 horizon material was modern (DIC-727) and indicates its residence time is not long.

The morphology of many of these soils displays an eluvial (E) horizon (see Appendix) from which iron and, presumably aluminum as well, have been removed. The removal is primarily due to the action of weak organic acids produced during the decomposition of organic residues. Oxides are translocated downward in the profile either in simple solution or as organo-metallic chelates. The reddish brown colors of the B horizon, heavy coating of $\mathrm{Fe}_{2} \mathrm{O}_{3}$ on sand grain surfaces in this horizon, the increase in both $\mathrm{CaCl}_{2}$ and $\mathrm{H}_{2} \mathrm{O}$ pH over the upper horizons and the relatively high organic carbon content support the idea that some leaching and weak chemical translocation and precipitation occurs. The olive colors of the $\mathrm{C}$ horizon which occur as permafrost is approached are indicative of iron in a reduced state.

The origin of the iron, aluminum and metal cations (e.g., calcium) is in part due to weak and protracted weathering of feldspars and such minerals as hornblend. Not far from the Atkasook area, Rickert and Tedrow (1966) described soils whose parent materials were sands of the Gubik Formation. Their analysis showed them to be composed of $95 \%$ quartz and chert $\left(\mathrm{SiO}_{2}\right)$ with some potash $(\mathrm{K})$ feldspar and an assemblage of heavy minerals including hornblende. Thus, the near absence of weatherable minerals, low precipitation, low soil temperature, weak organic acids produced from biochemical decomposition of lichens and other plants, and the short thaw period contribute to weak profile differentiation even over long periods of time on the most favorable site.

Cryopsamments with well expressed morphology represent long periods of stability of the primary landform surfaces however, many surfaces, even those of some primary landforms do not experience long periods of stability. They are subject to aperiodic and sporadic deflation and aeolian 
sedimentation. Thus, soil profiles may become truncated or buried. Excavation and natural exposures commonly show one or more well developed Cryopsamments below a modern soil that may range widely in its degree of development. In one exposure, two soils were buried beneath sands in which a weakly expressed Cryopsamment had developed. The A1 horizon of the lower soil whose profile indicated a long period of development gave a radiocarbon date of 5985 yr. B.P. (GX-5547). The upper much less well developed soil was $<200$ yr. B.P. (GX-5546). In an analogous situation on the Ikpikpuk River, Rickert and Tedrow (1966) obtained a date of $3840 \pm 140 \mathrm{yr}$. B.P. (I-1004) for an Alb horizon between 18 and $51 \mathrm{~cm}$ below the surface.

The morphologically well developed Cryopsamments of the primary landform surfaces at Atkasook are interpreted as displaying the maximum expression of the soil forming factors in well-drained materials - the zonal concept of earlier classifications (Baldwin et al., 1938). Counterparts of this soil are distributed widely north of the Brooks Range but nowhere do they form extensive or contiguous units. South of the Brooks Range the processes of acid leaching (Podzolization) strengthen. The B horizons of Pergelic Cryopsamments, especially those whose parent materials contain significant proportions of weatherable minerals, become more enriched in aluminum, iron and organic chelates and become transitional to true spodic horizons, and the soils transitional to Spodosols.

On topographic positions similar to primary landforms, but covered by more recent dune materials, are Pergelic Cryopsamments whose profiles are less well expressed than those just described. Vegetation on these younger surfaces is dominated by Cryptogams, although Alectoria nigricans is usually absent. The soil profile (see Appendix) either lacks an organic rich A1 horizon or has only a thin interrupted one. No eluvial (E) horizon is developed. The underlying $\mathrm{C}$ horizon(s) often displays weak mottling as the permafrost is approached. These Pergelic Cryopsamments are considered to be relatively young soils, probably less than 1000 years old. With increased site stability and time the soils will take on a morphology similar to those of the old and stable surfaces.

Pergelic Cryopsamments are also recognized in active and very recently active sand dunes. Temporary stabilization by widely spaced grasses, sedges or Salix spp. permit accumulation of small amounts of organic matter and the development of a thin, commonly discontinuous, slightly oxidized surface horizon. Below this horizon there is essentially no profile differentiation. Light olive brown colors persist to permafrost $(90$ to $115 \mathrm{~cm})$ and soil $\mathrm{pH}$ remains rather constant near 7 (Appendix). In the upper $80 \mathrm{~cm}$ soil moisture ranges from 4 to 50 percent (dry weight basis) - increasing generally with depth. Due to the high thermal conductivity of the uninsulated sands temperatures tend to be among the warmest of any of the soils in this area. In mid-August 1975 for example, the temperature at one site ranged from $19^{\circ} \mathrm{C}$ at $8 \mathrm{~cm}$ to $6^{\circ} \mathrm{C}$ at $92 \mathrm{~cm}$, whereas at $10 \mathrm{~cm}$ in a neighboring Cryaquept soil temperatures were near $0^{\circ} \mathrm{C}$ to $1.5^{\circ} \mathrm{C}$. Zones of Salix spp. roots representing static periods during dune accretion are common to depths of $50 \mathrm{~cm}$. 
Once such areas become stabilized by vegetation, the seasonal active layer begins to decrease in thickness. If the site is topographically elevated and remains relatively well-drained, soil development under relatively warm temperatures with acid leaching may proceed along a continuum in which organic acids and sesquioxides are released from the surface horizons and precipitated as oxidized coatings in the $B$ horizon, which becomes increasingly more red as the process continues. Eventually an eluvial (E) horizon will be developed. Soil reaction $(\mathrm{pH})$ will decrease in the solum horizons from near neutrality to moderately acid. The general instability of the region, especially near the Meade River, makes such a sequence rare.

The Pergelic Cryopsamments in topographically low and poorly drained areas may display mottling, and thus belong to an aquic subgroup (Aquic Pergelic Cryopsamments). These soils may evolve to Pergelic Cryaquepts as depth to permafrost decreases and/or moisture increases. Eventually the soils may become Histic Pergelic Cryaquepts as organic matter accumulation increases in the wet, anaerobic environment.

\section{Pergelic Cryofluvents}

These are fine textured (loamy very fine sands or finer) alluvial soils associated with the Meade River where they occupy narrow flood plains (commonly a few tens of meters in width).Such areas range in height above the river from $0.5 \mathrm{~m}$ to perhaps as much as $2 \mathrm{~m}$ and are subject to yearly spring flooding. As a consequence of this flooding, the soils display a banded or stratified morphology and texture, that reflects the energy state of the water at the time of deposition. Clay layers, usually high in organic carbon (some percentage of which may be coal derived from the Cretaceous bedrock) alternate with coarser textured layers (see Appendix). As a general rule the profile becomes coarser textured with depth and the organic carbon content also tends to decrease. The yearly influx of sediment effectively prevents the differentiation of soil horizons, even in these moderately well-drained sites.

Most of the alluvial soils support dense thickets of a willow (Salix alexensis) that may reach a height of $1.5 \mathrm{~m}$. Cessation of the yearly increment of sediment (as the river changes course and the floodplain is abandoned) results in the development of an effective insulating ground cover. Salix alexensis dies out as the permafrost aggrades. The soil then takes on the morphological (taxonomic) characteristics of a Pergelic Cryaquept. Analogous transformations occur on alluvial fans or terraces in the mountain region to the south where Pergelic Cryorthents removed from the influence of aperiodic sedimentation evolve along a course similar to that described the Cryopsamments or toward Cryaquepts.

As stated previously these soils are tentatively designated as Pergelic Cryofluvents. At present, the soil taxonomy specifically excludes the suborder of fluvents from a Pergelic temperature regime (for unspecified reasons). Because the alluvial soils of the Meade River-Atkasook area have a taxonomically acceptable morphology that developed due to the process of seasonal overbank flooding (alluviation) and a deep seasonal depth of thaw (75 $\mathrm{cm}$ ), it is suggested that they be recognized as Cryofluvents. 


\section{Inceptisols}

Aquepts: Aquepts or wet Inceptisols account for 36 percent of the surface of the Meade River-Atkasook area. In these soils, ground-water stands close to the surface during much of the thaw period. Because of the wet conditions in which many of them occur, thick organic surface horizons are common. Mineral horizons in most aquepts are mottled with greys and yellowish reds reflecting shifting aerobic and anaerobic conditions, either due to improved drainage as the seasonal frost recedes or to the flow of oxygenated shallow ground-water. Most of the aquepts appear to range in age up to 5,000 or 6,000 years. The better drained ones occupy tussock slopes and accentuated polygon rims.

Pergelic Cryaquepts: Pergelic Cryaquepts are the principal soils of the long, relatively uniform tussock tundra slopes in which mean August thaw is $26 \mathrm{~cm}$. In the Atkasook area such slopes account for about $20 \%$ of the surface.

Morphologically, the soil is complex and displays a wide range in thickness and characteristic horizons (see Appendix). This complexity is due in part to frost heaving. Profiles generally have an $\mathrm{O}$ horizon composed of coarse, fibrous organic materials seldom thicker than $8 \mathrm{~cm}$. If there has been little mineral addition, organic carbon content may reach 40 percent. The $O$ horizon may give way abruptly to a thin black A1 horizon with a significant loamy sand or silt loam mineral component. The organic material (except for roots) is usually decomposed to the point that its constituents cannot be identified. In some cases the organic carbon values may be as high as in the $\mathrm{O}$ horizon and the horizon is then designated $\mathrm{O} 2$. In other cases, especially under tussocks, a thick $O$ horizon of about $20 \mathrm{~cm}$ may develop. The presence of such an horizon places the soil in the histic subgroup of the Cryaquepts. Whether $\mathrm{O}$ horizons alone or in combination with an A horizon occur, they terminate abruptly on a B horizon that is moist to wet. The upper few centimeters of this horizon are oxidized and brown or dark brown in color. This color changes rapidly with depth to very dark greyish brown or grey indicative of anaerobic conditions.

The boundary between the $\mathrm{A}$ and $\mathrm{B}$ horizon or a region within less than 1 $\mathrm{cm}$ of it is commonly the site of organic-metallic precipitates. These deposits may take the form of coarse granules (sometimes mistakenly identified as charcoal) or as plates up to $0.5 \mathrm{~cm}$ in length. Analysis of the precipitates show them to be composed of 8-15\% iron, 17-26\% organic carbon, and from 45 to $400 \mathrm{ppm}$ manganese. Not coincidentally, the A-B horizon boundary is marked by an increase in $\mathrm{pH}$ from the range 4.2-4.7 to a range of 5.1-5.9. Both iron and manganese are released through microbial decomposition of organic materials (which also produces humic acids). Also, both metal ions exist in either of two valance states one of which is soluble, the other essentially insoluble. Which state occurs depends upon soil reaction and the presence or absence of oxygen. It is suggested that organic-metallic chelates formed in the course of organic decomposition in the $\mathrm{O} 2$ and $\mathrm{A} 1$ horizons move vertically and laterally early in the thaw season but are precipitated later when they encounter the aerobic/anaerobic and $\mathrm{pH}$ boundary near the top of the mineral 
B horizon. Similar precipitates are found associated with cracks that extend toward the surface or into B horizons.

In general, the B horizon of Aquepts is finer textured than the $C$ horizon (silt loams to loamy sands as opposed to sands). This may reflect the airborn input of clay and especially silt size materials derived from active sand dune areas and from the bottom of the Meade River which is exposed by mid-summer. The dark greyish brown and grey fine sands of the $\mathrm{C}$ horizon continue below the permafrost surface. The upper $20-40 \mathrm{~cm}$ or so of these permanently frozen sands contain numerous thin ice lenses, individually several millimeters in thickness, as well as fragments of sedge leaves, sheaths, roots and occasional inclusions of highly decomposed organic material (Al horizon). The organic materials have been radiocarbon dated at $5590 \pm 250 \mathrm{yr}$. B.P. (DIC 697). In other regions of the North Slope, organic material obtained by the author from similar sites range from 3500-8600 years B.P. Below about $40 \mathrm{~cm}$, root and leaf fragments occur only sporadically. Soil reaction $(\mathrm{pH})$ increases with depth in the permafrost and approaches 6.0 at a depth of about $50 \mathrm{~cm}$. Two possibilities suggest themselves: (1) a former (probably) weakly developed soil was removed, followed by more moist and stable conditions in which the tussock tundra developed or (2) tussock tundra and associated soils developed throughout the last 5,600 years by accretion of organic matter after sand stabilization occurred. Permafrost then moved upward in response to the better insulation provided by the organic material. The second interpretation is favored.

In the lee of many active or partly active dune areas are stabilized sloping sand sheets on which moderately wet Pergelic Cryaquepts are developing under mosses and sedges. The profiles consist of mottled sand below a thin $2-5 \mathrm{~cm} \mathrm{A1}$ horizon. Although many of these sites may be $400 \mathrm{~m}$ or more removed from active deflation pits, small piles of sand are formed on top of the moss. The sand has probably been added on the winter snow and later let down during spring melt. These young and weakly differentiated soils are interpreted as precursors of the tussock tundra soils which will develop if the sand sheets remain stable (e.g., the river abandons a cut bank). Soils of this type comprise about 8 percent of Pergelic Cryaquepts of the Atkasook site.

\section{Histosols}

Pergelic Cryohemists and Cryosaprists: These organic soils together with Histic and Humic Cryaquepts are found in the wet cellular or polygonized landscapes and comprise about 50 percent of the study area soils.

It is postulated that many of the polygonized or cellular microrelief areas arose in the basins of short lived lakes formed between crest ridges of primary and later cycle sand dunes and, in some instances, in the sloughs between point bars and meander cutoffs (see Fig. 3). Such areas persisted for perhaps several thousands of years as wet sedge meadows and string bogs receiving aperiodic aeolian deposits of sand and/or silt. At some point in time, ice wedge growth began to push up rims and define polygons. 
Each polygon or cell is composed of three elements: a center or basin that may contain up to $15 \mathrm{~cm}$ of water except in dry years, such as 1977 . Nearly pure stands of sedges (Carex chordorrhiza and $C$. aquatilis) are characteristic of the wetter centers, whereas $C$. aquatilis along with Salix pulchra and Betula nana typify the drier centers (Webber et al., 1977). Surrounding the center is a rim 1 to $2 \mathrm{~m}$ wide and from a few to $50 \mathrm{~cm}$ or more high. The lower rims may be discontinuous and have nearly the same vegetation as the drier centers. The better defined rims are almost always continuous and have vegetation composed of Dryas integrifolia, Salix pulchra, S. reticulata and Bistorta plumosa among others.

In many polygons, especially the wetter ones, a shelf composed of Sphagnum spp. and other mosses, extends out into the basin from the base of the rim. Rubus chamaemorus is the characteristic vascular plant. Rims may form distinct 4 to 7 sided polygon outlines around squarish to circular basins 8 to 12 meters in diameter. Other rims and basins assume an eliptical or complex irregular form where the individual cells may be many tens to 100 meters or more in length.

Associated with regular polygonal patterns is a trough a few $\mathrm{cm}$ to a meter or more wide and up to $50 \mathrm{~cm}$ deep that separates the rims of adjacent polygons. Many troughs contain water and have vegetation dominated by $C$. aquatilis. These troughs reflect the sites of underlying ice wedges. As the wedges grow they expand exerting pressure on the surrounding soil forcing it up into rims. In areas with large, diffuse and possibly older polygons, well defined troughs do not always occur, although a crack leading to the underlying ice wedge may be visible. It is possible that the origin of some of the rims associated with the diffuse polygons is in part an expression of strongmoor as well as cryoturbic forces.

Soils of the basin or center elements are with rare exceptions, Pergelic Cryohemists (see profile in Appendix). They are composed of sand and moderately decomposed (hemic) coarse to medium textured organic materials throughout their seasonally thawed depth $(40-45 \mathrm{~cm})$. Organic carbon values (see Appendix) are uniformly low, in many cases being just sufficient to permit the soil to be included within the Histosols (12-13\% organic carbon with the sandy texture). In cases where polygons are near sand sources, i.e., dunes or the river, mineral contents may reach such a level that organic carbon values fall short of the necessary 12 percent and the soil cannot be classified as a Histosol. No really suitable taxon currently exists for these soils and they are of necessity placed in the Inceptisols as Histic Pergelic Cryaquepts. Placement within the Entisols in the suborder Aquents seems more reasonable, however, for the present, soils containing permafrost are excluded from that suborder. Similar taxonomic difficulties have arisen in the coastal tundra areas adjacent to major drainages where loess additions have reduced the organic carbon percentage below the taxonomically acceptable levels for Histosols (Parkinson, 1978; Everett and Parkinson, 1977).

Most of the organic materials that comprise the rim elements had their origin in polygon center environments. Expansion of the bounding ice wedges 
has elevated these materials. In this better drained and warmer environment biological oxidation has converted hemic materials to sapric, or taxonomically, Cryohemists to Cryosaprists (Fig. 4). The organic oxidation produces a thinning of the $\mathrm{O}$ horizon and/or the relative enrichment of mineral materials due to a decrease in organic carbon percentage. A decrease in the soil reaction occurs and there may be precipitation of iron and/or manganese humates at the aeriation/pH boundary.

In cases where biological oxidation has reduced the thickness of the $O$ horizon(s) or has reduced the organic carbon values below the taxonomic requirements for Histosols, the resulting soil commonly displays a $20 \mathrm{~cm}$ or more thick dark colored A1 horizon over mottled sands of the B horizon. Such soils are classified as Humic Pergelic Cryaquepts and are the better drained analogs of Histic Pergelic Cryaquepts. Where the organic or organic rich horizon has been reduced to less than $20 \mathrm{~cm}$, the soil simply is classified as a Pergelic Cryaquept. In many cases the trough soils are morphologically and chemically similar to those of the polygon centers.

In places where surface drainage ways have intercepted areas of low centered polygons, thermokarst and thermal erosion combine to greatly deepen the troughs, essentially leaving the rim and center in a topographically higher and better drained environment. The rim elements quickly collapse into the deepening troughs and biological oxidation begins the conversion process of Cryohemists to Cryosaprists or Humic Pergelic Cryaquepts.

Age of the polygon landscapes: In polygon centers organic materials continue below the active layer into the permafrost to depths of at least $60 \mathrm{~cm}$ (Fig. 4). With depth the amount of organic material, its decomposition state and the degree of fragmentation vary widely from horizon to horizon. Generally at the

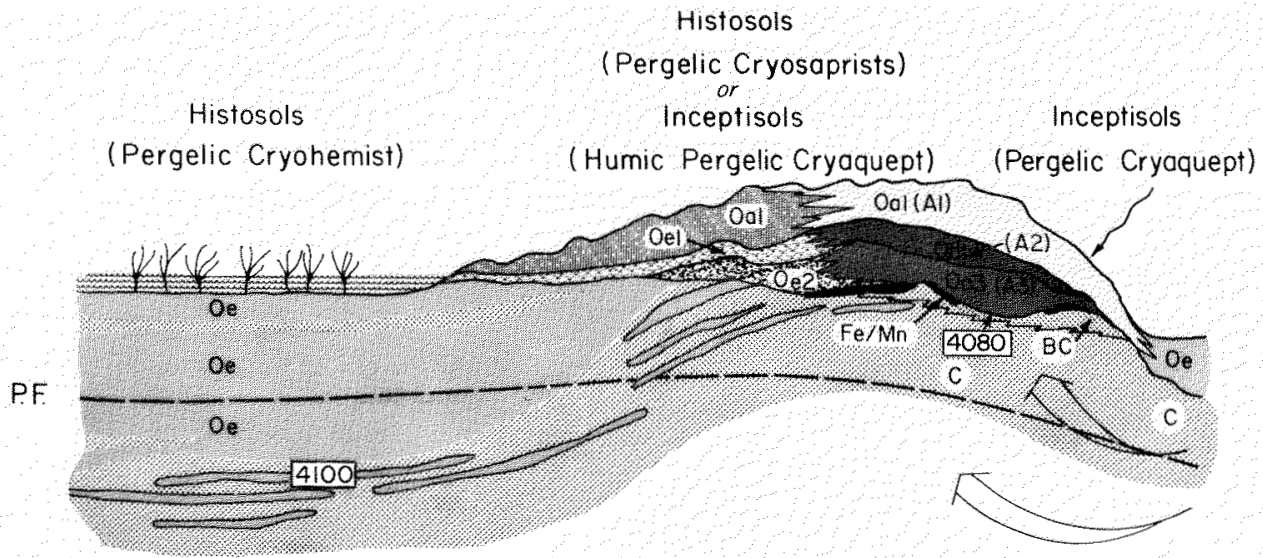

FIG. 4. Schematic cross-section of the soils in the transition area from the center (left) of a low center polygon to the trough.

Stippled area is sand; other patterns represent organic or organic-mineral materials. The soil horizon designation (e.g., Oe) indicates the stage of decomposition of these materials. The dashed line (P.F.) represents the August thaw depth. Open arrows depict forces exerted by an expanding ice wedge (just beyond the section). Typical radiocarbon years are indicated by the 4100 year and 4080 year dates. 
lower depths, the organic components are scattered leaf and stem fragments. Radiocarbon ages from organic materials from the basins of several polygons inland from the Meade River range from $4750 \pm 70 \mathrm{yr}$. B.P. (DIC 465 ) at $80 \mathrm{~cm}$ (total depth from surface) to $4080 \pm 135 \mathrm{yr}$. B.P. (DIC 696) at between 44 and $52 \mathrm{~cm}$. This latter depth is just below the base of the August active layer and the point at which organic materials become more fragmented and constitute a lower percentage in the sand (suggesting a former non-stable environment). The sand surface may have become stabilized sometime between 4,000 and 5,000 yr. B.P. A similar range in ages was found for well-developed low centered polygons in the Prudhoe Bay area (Everett, unpublished data).

A much older age was obtained from an inactive low centered polygon exposed in the cut bank of an active meander of the Meade River. The upper $30 \mathrm{~cm}$ of the polygon basin was composed of alternating layers of sand and thin organic accumulations that reflect active sand addition from the eroding bluff face. A coarse fibrous sedge peat similar to that accumulating in the basins of active polygons extends from $30 \mathrm{~cm}$ to $76 \mathrm{~cm}$ in depth. Below $76 \mathrm{~cm}$ to the last organic matter $(112 \mathrm{~cm})$ are somewhat contorted interbedded sands, organic-rich sands, and organic matter. The lowermost organic gave an age of $9470 \pm 145$ yr. B.P. (DIC 464). A similar "banded" sequence was found in a modern string bog immediately inland from the river bluff. There, at least three thin organic horizons are separated by sandy mineral materials. The bluff surface is the oldest dated in the area and may correspond in age to some of the primary landforms further inland.

On a terrace produced in a former meander of the Meade River that lies 5 to 6 meters below the top of the bluff section just described, a sample of peat 16 $\mathrm{cm}$ below the base of the August active layer $(48 \mathrm{~cm})$ gave an age of $3740 \pm$ 110 yr. B.P. (DIC 694). The material was again from a polygon center and consisted of sedge, fragmented leaves and stems estimated at 20-30\% by volume. The full thickness of these organic materials was not realized due to loss of the drill. An age of $2560 \pm 75 \mathrm{yr}$. B.P. (DIC 695) was obtained at the bottom of the active layer $(48 \mathrm{~cm})$ on moderately decomposed, fragmented, finely fibrous materials. Similar fragmented organic materials continued upward to $37 \mathrm{~cm}$. From that depth to the surface the organic materials were not fragmented. It seems likely that stabilization of this site and perhaps the instigation of the polygons themselves, beginning with the deposition of unfragmented organic materials, took place sometime after 2560 yr. B.P.

\section{SUMMARY}

The soils of the Meade River-Atkasook region and generally, of the sand region of the coastal plain, have developed distinctive morphologies related closely to landform, site stability and topographic setting. A time controlled evolutionary succession that can be used effectively in defining the gross pattern of landform development is demonstrated for soils of both wet and dry sites. 


\section{ACKNOWLEDGEMENTS}

This work was supported by National Science Foundation Grants \#OPP75-129.50-A01 as part of the multidisciplinary RATE (Research Applied to Tundra Environments) program conducted at Atkasook, Alaska. A number of colleagues have contributed to this manuscript through discussion, especially Vera Komárková and Kim Peterson. Nancy Grulke assisted me in the field in 1975 and 1976. The manuscript has benefited from a review by Richard P. Goldthwait and Daniel E. Lawson.

\section{REFERENCES}

BALDWIN, M., KELlOGG, C.E., and THORP, J. 1938. Soil classification. Yearbook of Agriculture, 87:979-1001.

BLACK, R.F. 1951. Eolian deposits of Alaska. Arctic, 4:89-111.

1964. Gubik Formation of Quaternary age in northern Alaska. United States Geological Survey Professional Paper 302-c:59-91.

CANTLON, J.E. 1961. Plant cover in relation to macro- meso- and micro-relief. Final report to the Arctic Institute of North America on contracts ONR208 and ONR212.

CARTER, L.D. and ROBINSON. S.W. 1978. Eolian sand and interbedded organic horizons at Kealok Creek on the arctic coastal plain of Alaska: possible regional implications. United States Geological Survey. Open file report 78-320.

Costin, A.B. 1955. A note on gilgaies and frost soils. Journal of Soil Science, 6:32-34.

EVERETT, K. R. and PARKINSON, R. J. 1977. Soil and landform associations, Prudhoe Bay area, Alaska. Arctic and Alpine Research, 9: 1-19.

KACZOROWSK1, R.T. 1977. The Carolina Bays: a comparison with modern oriented lakes. Coastal Research Division; Department of Geology, University of South Carolina, Columbia. Tech. Rept. No. 13-CRD.

LAWSON. D.E., BROWN, J, and EVERETT, K.R. 1978. The site (description) in Tundra disturbances and recovery following the 1949 exploratory drilling, Fish Creek northern Alaska. Lawson, D.E., Brown, J., Everett, K.R., Johnson, A.W., Komárkorá, V., Murry, B.M., Murry, D.F. and Webber, P.J. U.S.A. CRREL Report 78-28:3-7.

PARKINSON, R.J. 1978. Genesis and classification of arctic coastal plain soils, Prudhoe Bay, Alaska. Institute of Polar Studies, The Ohio State University, Columbus, Ohio, Report No. 68.

RICKERT, D.A. and TEDROW, J.C.F. 1966. Pedologic investigations on some aeolian deposits of northem Alaska. Soil Science 104:250-262.

SELKREGG, L.L. 1975. Alaska Regional Profiles, Arctic region. Environmental Information and Data Center, University of Alaska, Anchorage: 217.

SOIL SURVEY STAFF. 1975. Soil Taxonomy. United States Department of Agriculture Soil Conservation Service Agriculture Handbook No. 436: 754.

TEDROW. J.C.F. and HILL, D.E. 1955. Arctic Brown soils. Soil Science 80:265-275.

WARHAFtig, C. 1965. Physiographic divisions of Alaska. United States Geological Survey Professional Paper 482: 52.

WEBbER, P. J., KOMÁRKOVA, V., HANSELL, H. and SEABERT, K. 1977. Soil moisture and soil thaw data and their particle analysis from sixty vegetation plots at Atkasook, Alaska for the summers of 1975 and 1976. Unpublished data report. Institute for Arctic and Alpine Research, Univ. of Colorado, Boulder. 


\section{Appendix}

Some selected edaphic characters for the principal soils recognized in the Atkasook area

\begin{tabular}{|c|c|c|c|c|c|c|c|c|c|c|c|c|c|c|c|c|}
\hline \multirow[b]{2}{*}{ Taxon } & \multirow[b]{2}{*}{ Horizon } & \multirow[b]{2}{*}{$\begin{array}{c}\text { Depth } \\
\text { cm }\end{array}$} & \multirow[b]{2}{*}{ Color* } & \multirow[b]{2}{*}{ Texture } & \multirow[b]{2}{*}{ Struct. } & \multirow[b]{2}{*}{ Roots } & \multirow[b]{2}{*}{ Boundary } & \multirow[b]{2}{*}{$\mathrm{pH}_{\mathrm{w}}{ }^{* *}$} & \multirow{2}{*}{\multicolumn{2}{|c|}{$\mathrm{pH} \mathrm{CaCl}_{2} \underset{\mathrm{C}}{\text { Organic }}$}} & \multirow[b]{2}{*}{$\mathrm{Ca}$} & \multicolumn{5}{|c|}{ Exchangeable cations } \\
\hline & & & & & & & & & & & & $\begin{array}{c}\mathrm{meq} / 100 \\
\mathrm{Mg}\end{array}$ & $\stackrel{\mathrm{g}}{\mathrm{K}}$ & $\mathrm{ppm}$ & $\begin{array}{l}\% * * * \\
\mathrm{Fe}\end{array}$ & $\begin{array}{l}14 \\
\mathrm{C}\end{array}$ \\
\hline $\begin{array}{l}\text { Pergelic } \\
\text { Cryopsamment }\end{array}$ & $\begin{array}{c}\text { A1 } \\
\text { E } \\
\text { B21 } \\
\text { B22 } \\
\text { C } \\
\end{array}$ & $\begin{array}{c}0-6 \\
6-13 \\
12-30 \\
30-46 \\
46-66 \\
\end{array}$ & $\begin{array}{c}7.5 \text { YR2/2 } \\
5 \text { YR } 3 / 2 \\
5 \text { YR 3/3 } \\
7.5 \text { YR 4/4 } \\
2.5 \text { YR 4/4 } \\
\end{array}$ & $\begin{array}{l}\text { LS } \\
\text { S } \\
\text { S } \\
\text { S } \\
\text { S } \\
\end{array}$ & $\begin{array}{c}\text { Ns } \\
\text { Ns } \\
\text { C } \\
{ }^{\circ} \mathrm{b} \\
\text { Ns } \\
\end{array}$ & $\begin{array}{l}\mathrm{C} \\
\mathrm{C} \\
\mathrm{F} \\
\mathrm{A} \\
\mathrm{A}\end{array}$ & $\begin{array}{l}\mathrm{Ai} \\
\mathrm{Aw} \\
\mathrm{Aw} \\
\mathrm{Aw} \\
\mathrm{PF}\end{array}$ & $\begin{array}{l}4.6 \\
4.7 \\
5.1 \\
5.3 \\
5.4 \\
\end{array}$ & $\begin{array}{l}3.7 \\
3.8 \\
4.0 \\
4.1 \\
4.2\end{array}$ & $\begin{array}{l}12.7 \\
3.6 \\
1.9 \\
0.9 \\
0.7\end{array}$ & $\begin{array}{l}2.6 \\
0.8 \\
0.6 \\
0.4 \\
0.3 \\
\end{array}$ & $\begin{array}{l}0.7 \\
0.5 \\
0.4 \\
0.8 \\
0.4 \\
\end{array}$ & $\begin{array}{l}0.21 \\
0.06 \\
0.06 \\
0.05 \\
0.05\end{array}$ & $\begin{array}{l}22 \\
25 \\
55 \\
60 \\
68\end{array}$ & $\begin{array}{l}0.47 \\
0.45 \\
0.52 \\
0.47 \\
0.45\end{array}$ & yr. B.P. \\
\hline $\begin{array}{l}\text { Pergelic } \\
\text { Cryopsamment }\end{array}$ & $\begin{array}{c}\text { A1 } \\
\text { C1 } \\
\text { C2 } \\
\text { Alb } \\
\text { C3 } \\
\text { IIAlb/B2 } \\
\text { IIB } 22 / \mathrm{C} 4 \\
\text { C5 } \\
\text { C6 } \\
\text { C7 } \\
\text { C8/IIIAlb }\end{array}$ & $\begin{array}{c}0-3 \\
3-12 \\
12-23 \\
23-24 \\
24-33 \\
33-51 \\
51-57 \\
57-67 \\
67-71 \\
71-88 \\
88-106 \\
\end{array}$ & $\begin{array}{c}10 \mathrm{YR} 2 / 2 \\
2.5 \mathrm{Y} 5 / 4 \\
2.5 \mathrm{Y} 5 / 4 \\
10 \mathrm{YR} 2 / 2 \\
2.5 \mathrm{Y} 5 / 4 \\
10 \mathrm{YR} 3 / 3 \\
10 \mathrm{YR} 4 / 3 \\
2.5 \mathrm{Y} 5 / 4 \\
2.5 \mathrm{Y} 5 / 2 \\
2.5 \mathrm{Y} 4 / 2 \\
10 \mathrm{YR} 5 / 4-2 / 2 \\
\end{array}$ & $\begin{array}{c}\text { LS } \\
\text { S } \\
\text { S } \\
\mathbf{L S} \\
\mathbf{S} \\
\mathbf{L S} / \mathrm{S} \\
\mathbf{S} \\
\mathbf{S} \\
\mathbf{S} \\
\mathbf{S} \\
\text { S/LS } \\
\end{array}$ & $\begin{array}{l}\text { Ns } \\
\text { Ns } \\
\text { Ns } \\
\text { Ns } \\
\text { Ns } \\
\text { Ns } \\
\text { Ns } \\
\text { Ns } \\
\text { Ns } \\
\text { Ns } \\
\text { Ns }\end{array}$ & $\begin{array}{l}\text { F } \\
\text { F } \\
\text { F } \\
\text { F } \\
\text { C } \\
\text { C } \\
\text { F } \\
\text { F } \\
\text { A } \\
\text { A } \\
\text { A }\end{array}$ & $\begin{array}{c}\text { Aw } \\
\mathrm{Aw} \\
\mathrm{Ai} \\
\mathrm{Ai} \\
\mathrm{Aw} \\
\mathrm{Ai} \\
\mathrm{Aw} \\
\mathrm{Aw} \\
\mathrm{As} \\
\mathrm{As} \\
\mathrm{PF}\end{array}$ & & & & & & & & & $\begin{array}{c}<200 \\
598\end{array}$ \\
\hline $\begin{array}{l}\text { Pergelic } \\
\text { Cryopsamment }\end{array}$ & $\begin{array}{c}\text { A1 } \\
\text { B21 } \\
\text { B22 } \\
\text { B23/C1 }\end{array}$ & $\begin{array}{c}0-4 \\
4-14 \\
14-27 \\
27-76 \\
\end{array}$ & $\begin{array}{c}10 \text { YR } 3 / 2 \\
10 \text { YR } 3 / 3-4 / 3 \\
10 \text { YR } 3 / 3-4 / 3 \\
5 \text { YR } 5 / 6-5 / 8\end{array}$ & $\begin{array}{c}\text { LS/S } \\
\mathbf{S} \\
\mathbf{S} \\
\mathbf{S}\end{array}$ & $\begin{array}{l}\text { Ns } \\
\text { Ns } \\
\text { Ns } \\
\text { Ns }\end{array}$ & $\begin{array}{l}\mathrm{C} \\
\mathrm{F} \\
\mathrm{C} \\
\mathrm{A}\end{array}$ & $\begin{array}{l}\text { As } \\
\text { As } \\
\text { As } \\
\text { PF }\end{array}$ & $\begin{array}{l}5.5 \\
5.6 \\
6.1 \\
5.8\end{array}$ & & & & & & & & \\
\hline $\begin{array}{l}\text { Pergelic } \\
\text { Cryopsamment } \\
\end{array}$ & $\begin{array}{l}\mathrm{C} 1 \\
\mathrm{C} 2 \\
\end{array}$ & $\begin{array}{c}0-51 \\
51-114 \\
\end{array}$ & $\begin{array}{l}2.5 \text { Y } 5 / 4 \\
2.5 \text { Y } 5 / 4 \\
\end{array}$ & $\begin{array}{l}\text { fs } \\
\text { fs }\end{array}$ & $\begin{array}{l}\text { Ns } \\
\text { Ns }\end{array}$ & $\begin{array}{l}\mathrm{C} \\
\mathrm{F} \\
\end{array}$ & $\begin{array}{l}\text { C } \\
\text { PF }\end{array}$ & $\begin{array}{l}7.0 \\
7.0 \\
\end{array}$ & & & & & & & & \\
\hline $\begin{array}{l}\text { Pergelic } \\
\text { Cryaquept }\end{array}$ & $\begin{array}{l}\text { 01 } \\
\text { A1 } \\
\text { B3 } \\
\text { C1 } \\
\text { C2 } \\
\text { C3f }\end{array}$ & $\begin{array}{c}0-3 \\
3-5 \\
5-13 \\
13-23 \\
23-41 \\
41-46 \\
\end{array}$ & $\begin{array}{c}10 \mathrm{YR} 2 / 1 \\
7.5 \mathrm{YR} 2 / 1 \\
10 \mathrm{YR} 4 / 2 \\
2.5 \mathrm{Y} 4 / 2 \\
2.5 \mathrm{Y} 3 / 2 \\
10 \mathrm{YR} 4 / 2\end{array}$ & $\begin{array}{l}\text { O } \\
\text { Ls } \\
S \\
S \\
S \\
S\end{array}$ & $\begin{array}{c}\text { Fi } \\
\text { Plwf } \\
\text { Plwf } \\
\text { Plwf } \\
\text { Ns } \\
-\end{array}$ & $\begin{array}{l}\text { C } \\
\text { C } \\
\text { C } \\
\text { F } \\
\text { F } \\
\text { A }\end{array}$ & $\begin{array}{l}\text { As } \\
\text { As } \\
\text { As } \\
\text { As } \\
\text { PF } \\
-\end{array}$ & $\begin{array}{l}\overline{5.2} \\
5.6 \\
5.5 \\
4.3 \\
5.2\end{array}$ & $\begin{array}{l}- \\
5.2 \\
4.9 \\
4.5 \\
4.2 \\
4.5\end{array}$ & $\begin{array}{l}4.7 \\
1.8 \\
0.5 \\
1.4 \\
0.7\end{array}$ & $\begin{array}{l}\overline{7.0} \\
2.5 \\
0.6 \\
0.4 \\
0.4\end{array}$ & $\begin{array}{l}\overline{2.2} \\
0.8 \\
0.4 \\
0.3 \\
0.2\end{array}$ & $\begin{array}{l}\overline{0.21} \\
0.06 \\
0.04 \\
0.05 \\
0.05\end{array}$ & $\begin{array}{l}\overline{212} \\
172 \\
42 \\
35 \\
75\end{array}$ & $\begin{array}{l}\overline{0.50} \\
0.52 \\
0.27 \\
0.31 \\
0.52\end{array}$ & \\
\hline
\end{tabular}




\section{Appendix}

Some selected edaphic characters for the principal soils recognized in the Atkasook area

\begin{tabular}{|c|c|c|c|c|c|c|c|c|c|c|c|c|c|c|c|c|}
\hline \multirow[b]{2}{*}{ Taxon } & \multirow[b]{2}{*}{ Horizon } & \multirow[b]{2}{*}{$\begin{array}{l}\text { Depth } \\
\text { cm }\end{array}$} & \multirow[b]{2}{*}{ Color* } & \multirow[b]{2}{*}{ Texture } & \multirow[b]{2}{*}{ Struct. } & \multirow[b]{2}{*}{ Roots } & \multirow[b]{2}{*}{ Boundary } & \multirow[b]{2}{*}{$\mathrm{pH}_{\mathrm{w}}{ }^{* *}$} & \multirow{2}{*}{\multicolumn{2}{|c|}{$\mathrm{pHCaCl}_{2} \stackrel{\text { Organic }}{\mathrm{C}}$}} & \multirow[b]{2}{*}{$\mathrm{Ca}$} & \multicolumn{5}{|c|}{ Exchangeable cations } \\
\hline & & & & & & & & & & & & $\begin{array}{c}\mathrm{meq} / 100 \\
\mathrm{Mg}\end{array}$ & $\underset{\mathrm{K}}{\mathrm{g}}$ & ppm & $\begin{array}{c}7^{* * *} \\
\mathrm{Fe}\end{array}$ & $\stackrel{14}{C}$ \\
\hline $\begin{array}{l}\text { Humic Pergelic } \\
\text { Cryaquept }\end{array}$ & $\begin{array}{l}\text { A1 } \\
\text { A12 } \\
\text { B2 } \\
\text { B23 } \\
\text { Alb } \\
\text { A12bf }\end{array}$ & $\begin{array}{c}0-5 \\
5-15 \\
15-25 \\
25-30 \\
30-37 \\
37-64\end{array}$ & $\begin{array}{c}5 \text { YR } 3 / 2 \\
5 \text { YR } 3 / 2 \\
7.5 \text { YR } 3 / 2 \\
7.5 \text { YR } 3 / 2 \\
10 \text { YR } 2 / 1 \\
10 \text { YR } 2 / 1\end{array}$ & $\begin{array}{c}\text { LS } \\
\text { SL } \\
\text { LS } \\
\text { S } \\
\text { LS } \\
\text { Ls }\end{array}$ & $\begin{array}{l}\text { Ns } \\
\text { Ns } \\
\text { Cs } \\
\text { Ns } \\
\text { Ns } \\
-\end{array}$ & $\begin{array}{l}\text { C } \\
\text { F } \\
\text { F } \\
\text { A } \\
\text { A } \\
\text { A }\end{array}$ & $\begin{array}{l}\text { Aw } \\
\text { As } \\
\text { As } \\
\text { As } \\
\text { PF } \\
\text { - }\end{array}$ & $\begin{array}{l}4.0 \\
4.6 \\
4.6 \\
5.3\end{array}$ & $\begin{array}{l}3.4 \\
3.9 \\
4.1 \\
4.2\end{array}$ & & $\begin{array}{l}9.3 \\
9.5 \\
1.5 \\
0.1\end{array}$ & $\begin{array}{l}3.3 \\
3.5 \\
0.2 \\
0.1\end{array}$ & $\begin{array}{l}0.78 \\
0.79 \\
0.03 \\
0.02\end{array}$ & $\begin{array}{c}163 \\
33 \\
4 \\
4\end{array}$ & $\begin{array}{l}2.10 \\
1.00 \\
0.35 \\
0.27\end{array}$ & 4080 \\
\hline $\begin{array}{l}\text { Pergelic } \\
\text { Cryohemist }\end{array}$ & $\begin{array}{l}\text { Oe } \\
\text { Oe1 } \\
\text { Oe2 } \\
\text { C1 } \\
\text { C2 } \\
\text { Oe4 } \\
\text { Oef }\end{array}$ & $\begin{array}{l}0-10 \\
10-23 \\
23-31 \\
31-36 \\
36-41 \\
41-43+ \\
76-79\end{array}$ & $\begin{array}{c}10 \mathrm{YR} 3 / 2 \\
10 \mathrm{YR} 3 / 3 \\
10 \mathrm{YR} 3 / 2 \\
10 \mathrm{YR} 3 / 2 \\
10 \mathrm{Yr} 2 / 1 \\
10 \mathrm{YR} 3 / 3\end{array}$ & $\begin{array}{l}\text { OS } \\
\text { OS } \\
\text { OS } \\
\text { SL } \\
\text { SL } \\
\text { OSL }\end{array}$ & $\begin{array}{l}\text { Plwf } \\
\text { Plwf } \\
\text { Ns } \\
\text { Ns } \\
\text { Ns } \\
\text { Plw }\end{array}$ & $\begin{array}{l}\text { C } \\
\text { C } \\
\text { C } \\
\text { F } \\
\text { F } \\
\text { A }\end{array}$ & $\begin{array}{l}\text { Cs } \\
\text { As } \\
\text { Aw } \\
\text { As } \\
\text { As } \\
\text { PF }\end{array}$ & $\begin{array}{l}5.0 \\
5.2 \\
5.0 \\
5.0 \\
5.0 \\
4.9\end{array}$ & $\begin{array}{l}4.4 \\
4.4 \\
4.4 \\
4.3 \\
4.3 \\
4.3\end{array}$ & $\begin{array}{c}12.8 \\
14.9 \\
12.0 \\
7.6 \\
4.6 \\
12.4\end{array}$ & $\begin{array}{l}3.1 \\
3.1 \\
3.7 \\
4.0 \\
3.1 \\
5.1\end{array}$ & $\begin{array}{l}1.5 \\
1.1 \\
1.2 \\
0.7 \\
0.6 \\
0.9\end{array}$ & $\begin{array}{l}0.23 \\
0.12 \\
0.10 \\
0.08 \\
0.07 \\
\$ .09\end{array}$ & $\begin{array}{l}45 \\
30 \\
20 \\
25 \\
25 \\
45\end{array}$ & $\begin{array}{l}0.59 \\
0.55 \\
0.59 \\
0.49 \\
2.38 \\
0.06\end{array}$ & 4750 \\
\hline $\begin{array}{l}\text { Pergelic } \\
\text { Cryofluvent } \dagger\end{array}$ & $\begin{array}{l}\text { C1 } \\
\text { C2 } \\
\text { C3 } \\
\text { C4 } \\
\text { C5 }\end{array}$ & $\begin{array}{c}0-8 \\
8-13 \\
13-20 \\
20-46 \\
46-76\end{array}$ & $\begin{array}{c}10 \mathrm{YR} 4 / 2 \\
10 \mathrm{YR} 3 / 2 \\
10 \mathrm{YR} 4 / 2 \\
10 \mathrm{Yr} 6 / 3 \\
10 \mathrm{YR} 6 / 3-8 / 2\end{array}$ & $\begin{array}{c}\text { SL } \\
\text { SL } \\
\text { fSCL } \\
\text { fSCL } \\
\mathbf{S}\end{array}$ & $\begin{array}{c}\text { Ns } \\
\text { Ns } \\
\text { B } \\
\text { B } \\
\text { B }\end{array}$ & $\begin{array}{l}\text { C } \\
\text { F } \\
\text { C } \\
\text { F } \\
\text { A }\end{array}$ & $\begin{array}{l}\text { Aw } \\
\text { Aw } \\
\text { Aw } \\
\text { Aw } \\
\text { PF }\end{array}$ & $\begin{array}{l}5.2 \\
4.9 \\
5.3\end{array}$ & $\begin{array}{l}4.6 \\
4.2 \\
4.4\end{array}$ & & $\begin{array}{l}12.6 \\
7.3 \\
7.7\end{array}$ & & & & & \\
\hline
\end{tabular}

* munsell; ${ }^{* *}$ 1:1 soil-water; ${ }^{* *}$ dithonite extractable; $†$ not a recognized taxon

Boundaries: Ai abrupt interrupted; As abrupt smooth; Aw abrupt wavy; Cs clear smooth.

Structure: Ns structureless; C weakly prismatic; B angular blocky; Fi fibrous; Pl platy; w weak; f fine

PF permafrost

$$
\text { s strong; c course }
$$

